SMART Journal, Volume 6, No. 2, August 2020, Page 108- 117

ISSN Cetak : 2356-2048

ISSN Online : :2356-203X

\title{
THE EFFECT OF REFLECTION IN LESSON STUDY
}

\author{
Imaniar Tiara Ningrum ${ }^{1)}$, Rahmatika Kayyis ${ }^{2)}$, Miftahul Jannah ${ }^{3)}$, Kurniati $^{4)}$, Fitri \\ Wulandari $^{5)}$, Renita Sigesti ${ }^{6}$ \\ 1) 2) 4) 5) English Education Department of FKIP UMPRI \\ Email Correspondence: imaniartiaraningrum@gmail.com
}

\begin{abstract}
This descriptive qualitative research aimed to describe, explain and analyzing about the impact of Lesson Study Reflection towards teachers ability in teaching English Language and to find out the impact of lesson study in teaching and learning process in $8^{\text {th }}$ B Class of SMP IT Insan Mulia Borading School Prigsewu. The data collection technique uses questionnaires and documentation. Data analysis uses Interactive. The result of this research presented that Lesson Study improve the quality of teaching-learning process, the students enthusiasm in learning English improved step by step as the lesson goes on, and it affect students learning outcomes.
\end{abstract}

Keywords: Lesson study, Reflection, English teaching

\section{INTRODUCTION}

English is one of language that used to communicate in the world as international language. According to Nunan in Cahyono (2010) English has become a tool for communication in transportation, commerce, banking, tourism, process of technology, diplomacy, and scientific research. The science and technology are conveyed using English

English language has been commonly accepted as an active universal language in the world. English is one of the most commonly spoken languages for economic, social and cultural prosperity in contemporary global society and, as a result, has become a worldwide enterprise (Kubota \& Lin, 2006). Therefore, nowadays students ought to master English as a foreign language. In teaching learning process, particularly in teaching language, sometimes teacher rarely considers whether what they say in class is able to encourage the students to be active or not. As the fact, the teaching of English in our formal education was somehow out of the expectation. There are so many

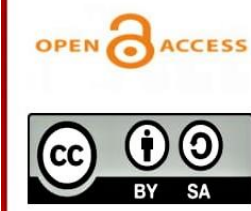

Creation is distributed under the Creative Commons License Attribution Share Alike 4.0 International Published in https://ejournal.umpri.ac.id/index.php/smart/index

SMART Journal: Journal of English Language Teaching and Applied Linguistics 
English teachers do not succeed in teaching English as a foreign language. From these facts, it seems that something is incorrect from their teaching and learning English activity.

Teachers have an important role in making academic atmosphere. To achieve this, they need to be professional in improving the quality of their teaching and learning process. In addition, to be professional teachers, they need to explore their teaching knowledge and experiences. Improving teacher quality must be done in a fundamental and comprehensive manner. The most effective improvement in the quality of learning can be done with lesson study, Madawati (2015) states the formulation of Lesson Study as one of the models of teaching professional development through the study of collaborative and sustainable learning based on the principles of collegiality and mutual learning to build learning communities. There are some previous studies taken by some researchers around the world related to the use of Lesson Study to help the teacher to conduct the class in the learning activity. The first study was conducted from Nashruddin (2016). The researcher conduct the research in a private senior high school in Malang, East Java, Indonesia with the title "The Implementation of Lesson Study in English Language Learning” As this is a case study, it only focus on a school and the result should not be used to generalize Lesson Study applications in Indonesia.

In the lesson study there are several stages that must be carried out including the planning stage, the implementation stage and the reflection stage. At the plan stage, all participants hold discussions regarding the learning activities that will be implemented. Then at the "do" stage the lesson plan that was created will be implemented by the teacher in the class. for the next stage is reflection "see", there will be a discussion related to learning activity, Therefore, the researcher conducted Lesson study at SMP IT Insan Mulia Boarding School Pringsewu to see the impact of lesson study especially the effect of reflection 
towards teaching and learning process in English learning, and explain findings that useful in the development of English teaching that will be done collaboratively by the teacher based on the principles of collegiality. The second previous study was conduct from Andini (2016). The researcher conduct the research in Introduction to literature class of English Language Education Department FKIP UMM entitle "Implementation of Lesson Study for Improving the Quality of Student Learning Process" it research was conduct in two cycle, with three meeting in the first cycle and four meeting in the last cycle. In the cyle1, it improve the students enthusiast in learning, the students enjoyed to learning, they could improve their participation in the teaching learning process, and their attitudes toward the learning activity significantly improved.

In the lesson study there are several stages that must be carried out including the planning stage, the implementation stage and the reflection stage. At the plan stage, all participants hold discussions regarding the learning activities that will be implemented. Then at the "do" stage the lesson plan that was created will be implemented by the teacher in the class. for the next stage is reflection "see", there will be a discussion related to learning activity, Therefore, the researcher conducted Lesson study at SMP IT Insan Mulia Boarding School Pringsewu to see the impact of lesson study especially the effect of reflection towards teaching and learning process in English learning, and explain findings that useful in the development of English teaching that will be done collaboratively by the teacher based on the principles of collegiality.

\section{RESEACH METHOD}

The design of this study was descriptive analysis in form of Descriptive Qualitative Research about analysis on the effect of reflection in lesson study. The researcher took from Creswell's note that the descriptive research attempts to describe, explain and interpret conditions of the present the purpose of a 
descriptive research is to examine a phenomenon that is occurring at a specific place and time. This study was conducted at SMP IT Insan Mulia Boarding School Pringsewu, which is located on Pringsewu, Pringsewu district, Pringsewu regency, Lampung province. This school has 4 classes for the elevengrade students. In this research, the researcher takes $8^{\mathrm{Th}} \mathrm{B}$ class students of SMP IT Insan Mulia Boarding School Pringsewu, This class had 29 students. To achieve the objectives of this study, data were collected in several techniques, namely interview and questionnaire containing about the implementation of lesson study, it was given to the model teacher, colleague teacher, English lectures and the students, and also observation class.

In this study, the researcher used technique of data analysis based on Miles and Huberman cited Sugiyono (2014) which is involving three steps: reduction data, displaying data, and conclusion drawing/verification. Those components of analysis are interrelated during research process.

\section{FINDINGS AND DISCUSSION}

According to Lewis (in Ibrahim 2011) explained that Lesson Study is a way effective that can improve the quality of teacher teaching and student learning activities. Lesson Study is not a method or learning strategies but lesson study activities can apply methods for learning strategies that are suitable for situations, conditions, and problems faced by the teacher. In this research lesson study can improve the teacher teaching and learning quality in English language. The reseracher provides an analysis of the findings in each lesson study cycle on the teacher and students. Those findings would be anayze as follow:

\section{a. Learning method and media}

According to the research result, teachers did not use variations method and media in their teaching leaarning but after implementing lesson study, There were various inovation in developing the learning method and media, lesson 
study Lesson Study helped teachers in developing the teaching and learning method

\section{b. Teacher's teaching ability in overcoming the learning practice and students activity in class}

In this research found that, Most of time Teacher's ran the learning activity without structured planning, and teacher was not accustomed to reviewing the process and activity in learning, but after implementing lesson study, teacher's teaching and learning pracice was better and stuctured based on lesson plan, and teachers was accustomed to reviewing the learning process and activities during open class, so it conclude that Lesson study improved the ability of teacher's teaching practice.

\section{c. Cooperation and coordination between allied teachers}

From the result of interview and questionnaire data, teachers has never been involved in each other class and there was never been collaboration between allied teacher in handling the learning acitivity. But teachers were involved in allied teacher teaching learning activities and created a collaboration in teaching and learning practice with allied teacher during lesson study implementation. Lesson study provide the opportunity for teachers to share their experience, insight, information and ideas.

\section{d. Teacher's learning evaluation}

Based on the research result the teacher tend not to conduct learning evaluation regularly in their daily teaching and learning practice, but Learnig evaluation was carried out by teachers during implementation of lesson study after open class, so by implementing lesson study there is an inovation to evaluate the learning activity.

Based on the data description above, it can be concluded that there are a positive effect of Lesson Study on the imrovement of teacher's teaching quality in English class, through lesson study teachers could use various methohd in 
their teaching practice in order to make the learning activity more interesting, Lesson Study also establish good cooperation and mutual learning between allied teacher. Furthermore, the students also made significant progress in learning after the implementation of Lesson Study. The progress could be seen as follow:

\section{a. Students Response}

In this research, the students response in cycle 1 was not really good but there were students who responses toward the learning activity,students answered the teachers question aout kinds of greeting card, but there were a students showed a low response and answered randomly, and in cycle 2 they had a low response toward learning activity at the beginning of the lesson, there were students looked not interest in following the lesson, there were some students put their head on table, and answered the teacher's question limply. But they became more active as the lesson goes on. The students responses was preety good improve in the last cycle.

\section{b. Student's comprehending}

In first open class the students comprehending about the material was good for the first meeting, but there were a few Students had low comprehension about the kind of greeting card. Students comprehending about the material was improved in second open class. All students could make an outline When teacher asked them to make it and some of students had already made it in form of actual greeting card. The students comprehending about the material was imroved each meeting, in third open class student could make a full greeting card and design it by themselve.

\section{c. Students dessire in learning}

Based on the research observation, in first open class, there were students had less desire in learning teaching activity, there was a student slept during the learning process at the beginning, but awakened in the middle of lesson, there 
was also students who chitchatted and make a noise with their friends. But there were students who had enthusiast in following the lesson. In second open class the students desire in learning looked weak at the beginning, they tend to be quiet when teacher entered the class but at the last open class Students looked more passionate in following the lesson there was a sense of competitive between each group, and all students tried to make the best greeting card. There was a sense of competitive between each group, and all students tried to make the best greeting card

\section{d. Students concentration in learning}

In first open class students paid attention on the teachers explanation and they looked concentrate when teacher displayed the kind of greeting card on projector screen, and in second open class there was a lowering concentration at the beginning of lesson, but their concentration lived up when teacher asked them to make an outline, there were students who asked to the teachers when they found difficulty, and there was student who opened the book and dictionary during outlining process. Students also could answered when teacher asked about part of greeting card that been showed before in projector screen, but their concentration was improved in the open class, students concentration was good, all students tried to design the greeting card. Some students translating the sentence into English, creating trinkets, drawing the paper and writing the greeting card.

\section{e. Students awarness}

Based on the research observation during lesson study implementation, in first open class only one group had chance to presenting their discussion result, the rest could not presented their disscusion related to the greeting card because the time was not enough, and there was no studnets awarness abou time. Students awarness when completing the lask was improve in second open class all group could finish their outline on time. And in last open class students collected their 
greeting card to the teachers on time, only two group was ingnoring the time and late.

Based on those explanations, there were some benefits of the implementation of Lesson Study in teaching-learning process. For the teacher, lesson study had made the leraning-teaching qulaity improved and more structural. For the students, lesson study had made the students more understanding the material, and lived up their enthusiasm in learning. The result of lesson study implementetation in SMP IT Insan Mulia Boarding School Pringsewu showed an improvement in each open class.

\section{CONCLUSION}

Based on the descricption of reasearch result and disccussion, it could be conclude that Lesson Study helped the teachers to improve their teaching learning quality, and through reflecting the lesson study implementation, the lesson study provides a positives impact on the English teaching and learning including :

1. The the learning implementation became more structured because teachers had made the lesson plan in chapter design acitivity, although there were some obstacles in each meeting, but it could be resolve in reflection stage. Teacher's teaching ability improved during lesson study implementation, because all the weakness in teaching practice discussed it reflection stage, so the further teaching practice be better than the pevious meeting, and lesson plan for next meeting made based on the various ideas from lesson study participants that concidered the result of reflection.

2. Lesson study generate the positive manner where the teacher accustomed to have maximum preaparation before learning in class. The teacher's habit in designing and preparing lesson plan has been formed. 
3. Through lesson study the comunication between allied teachers is quite good and it tends to improve the way teachers model teach, because there was no discussion about the learning practice between the allied teachers before.

4. Lesson study can help teachers in solving the learning problem because lesson studty provide the teacher to discussing and sharing the information together, and teachers became more inovative in using the method/strategy in learning practice, through lesson study teacher beacome more esier to understanding the student's behaviour and needs during the learning process.

5. Lesson Study implementation increased the students enthusiasm in learning English because there was a significant progress in each open class during Lesson study implementation, students enthusiasm improved step by step as the lesson goes on, and it affect students learning outcomes, due to the increasing of studnets score. Students enthusiasm was improved because in Lessson Study teacher solve the problem and discussing about the learning strategy that appopirate to students need. According to Kurniati \& Wulandari (2019) implementation implementing peer tutor in lesson study activities can make the process of learning to be organized, and can be exploiting an critical idea and it rise collaborative in group in anticipate out of condition in learning process.

\section{REFERENCES}

Andini, T.M (2016). Implementation of Lesson Study for Improving the Quality of Student Learning Process. Thesis. Malang: FKIP UMM.

Chichibu T., (2013). How Japanense Schools Build a Profesional Learning Community by Lesson Study? International Journal for Lesson Studies. Emeral Group Publishing Limited. Vol 2: 12-25

Doig, B \& Grover S. (2011). Japan Lesson Study: Teacher Professional Development trough Communities of Inquiry. Mathematics Teacher 
and Development 13(1), 7793. January 24, 2020. https://files.eric.ed.gov/fulltext/EJ960950.pdf.

Hendayana, Sumar, et al. (2006). Lesson Study, Suatu Strategi untuk Meningkatkan Keprofesionalan Pendidik (Pengalaman IMSTEPJICA). Bandung: UPI Press.

Indika, Norma. (2017). A Descriptive Analysis on Lesson Study Program Used by English Teacher in Seventh Grades of Smp Muhammadiyah Al-Kautsar Program Khusus Kartasura. Thesis.Surakarta :IAIN Surakarta.

Nashruddin, W \& Nurrachman, D., (2016). The Implementation of Lesson Study in English Language Learning. Thesis. Cirebon : Syekh Nurjati State Institute.

Pratiwi, I.A; Utaminingsih, S.; \& Murtono (2018). Effectiveness of Lesson Study Learning Community Models to Improve Learning Quality. Thesis. Central Java: Muria Kudus University.

Richards, J. C. and Renandya, W. A. (2002). Methodology in Language Teaching: an Anthology of Current Practice. Cambridge: Cambridge University Press.

Kurniati \& Wulandari. (2019). Peer Tutor in Lesson. Jurnal SMART. 5(2): $108-118$

Sudaryono. (2019). Metodologi Penelitian Kuantitatif, Kualitatif, dan Mix $\operatorname{Method}\left(2^{\text {nd }} E d\right)$. Depok: Rajawali Pers.

Sugiyono. (2013). Metode Penelitian Pendidikan (Pendekatan Kuantitatif, Kualitatif, dan $R \& D)$. Bandung: Alfabeta.

Yoshida, M. (1999). Lesson study: A Case Study of a Japanese Approach to Improving Instruction Through School-Based Teacher Development. Disertasi Ijazah Kedoktoran, The University of Chicago. 